\title{
PENINGKATAN KEMAMPUAN PEMAHAMAN KONSEP MATEMATIS MELALUI MODEL PEMBELAJARAN BERBASIS MASALAH BERBANTUAN AUTOGRAPH DAN GEOGEBRA DI SMA FREEMETHODIST MEDAN
}

\author{
Ismail Hanif Batubara \\ Dosen Program Studi Pendidikan FKIP UMSU \\ ismailhanif974@yahoo.com
}

\begin{abstract}
This research is aimed to know: (1) Whether the increasing of mathematical concept understanding ability students through problem-based learning model assisted Autograph better than the increasing of mathematical concept understanding ability students through problem-based learning model assisted Geogebra, (2) How the interaction between learning and early math ability of student mathematical concept understanding, The population are all students of SMA Free Methodist Medan. Then randomly selected two classes of four classes. The first experimental class were treated by problem-based learning model with assisted Autograph and the second experimental grade treated by problem-based learning model with assisted Geogebra. Data analysis was performed by analysis of variance (ANOVA) and two lanes. The research shows that: (1) The increasing of mathematical concept understanding abilities students through problem-based learning model assisted Autograph better than the increasing of mathematical concept understanding abilities students through problem-based learning model assisted Geogebra. (2) There is no Interaction between learning and early math ability of student mathematical concept understanding ability.
\end{abstract}

Keywords: Problem Based Learning, Autograph, Geogebra, Concept Understanding

\begin{abstract}
Abstrak. Tujuan dari penelitian ini adalah untuk mengetahui: (1) Apakah peningkatan kemampuan pemahaman konsep matematik siswa melalui model pembelajaran berbasis masalah berbantuan Autograph lebih baik daripada peningkatan kemampuan pemahaman konsep matematik siswa yang memperoleh model pembelajaran berbasis masalah berbantuan Geogebra, (2) Bagaimanakah interaksi antara pembelajaran dengan kemampuan awal matematik siswa terhadap peningkatan kemampuan pemahaman konsep. Populasi penelitian adalah seluruh siswa SMA Free Methodist Medan. Secara acak, dipilih dua kelas dari empat kelas. Kelas eksperimen I diberi perlakuan model pembelajaran berbasis masalah berbantuan Autograph dan kelas eksperimen II diberi perlakuan pembelajaran berbasis masalah berbantuan Geogebra. Analisis data dilakukan dengan analisis varians (ANAVA) dua jalur. Hasil penelitian menunjukkan (1) peningkatan kemampuan pemahaman konsep matematik siswa SMA melalui model pembelajaran berbasis masalah berbantuan Autograph lebih tinggi daripada peningkatan kemampuan pemahaman konsep matematik siswa yang memperoleh model pembelajaran berbasis masalah berbantuan Geogebra. (2) Tidak terdapat interaksi antara pembelajaran dengan kemampuan awal siswa terhadap kemampuan peningkatan pemahaman konsep matematik.
\end{abstract}

Kata Kunci: Pembelajaran Berbasis Masalah, Autograph, Geogebra, Pemahaman Konsep

\section{PENDAHULUAN}

Salah satu pembelajaran yang dipelajari di sekolah dan mempunyai peranan penting dalam kehidupan sehari-hari adalah matematika. Berbagai cabang matematika mulai dari aljabar, statistik hingga kalkulus memiliki terapan pada semua ilmu pengetahuan modern dewasa ini. Matematika kemudian berkembang menjadi dua 
bagian, pertama adalah matematika murni atau matematika sains yang diperuntukkan untuk matematika itu sendiri sebagai suatu cabang ilmu pengetahuan yang akan terus berkembang. Kedua adalah matematika terapan, dimana cabang-cabang ilmu lainnya mengadopsi matematika yang dikembangkan oleh matematika murni untuk dapat digunakan pada cabang-cabang ilmu tersebut.

Matematika dengan berbagai peranannya menjadikannya sebagai ilmu yang sangat penting, dan salah satu peranan matematika adalah sebagai alat berpikir untuk mengantarkan peserta didik memahami konsep matematika yang sedang dipelajarinya. Kemampuan pemahaman matematis sangat dibutuhkan oleh siswa dalam menarik sebuah kesimpulan sehingga seorang siswa mampu menyelesaikan persoalanpersoalan matematika.

Pentingnya pemahaman konsep ini dijelaskan oleh purwanto (1995:35) yang mengungkapkan bahwa pemahaman konsep adalah tingkat kemampuan yang mengharapkan peserta didik mampu memahami konsep, situasi, dan fakta yang diketahui, serta dapat menjelaskan dengan kata-kata sendiri. Hal senada juga dikatakan oleh Sanjaya (2006:36) menjelaskan bahwa pemahaman konsep adalah kemampuan peserta didik yang berupa penguasaan sejumlah materi pelajaran, dimana peserta didik tidak sekedar mengetahui atau mengingat sejumlah konsep yang dipelajari, tetapi mampu mengungkapan kembali dalam bentuk lain yang mudah dimengerti, memberikan interprestasi data dan mampu mengaplikasikan konsep yang sesuai dengan struktur kognitif yang dimilikinya.

Namun faktanya banyak siswa yang tidak suka dengan matematika. Kurang sukanya siswa terhadap matematika jika dilihat dari individu siswa itu sendiri dapat disebabkan karena banyak faktor seperti kecerdasan, minat, cita-cita hingga latar belakang keluarga dan lingkungan dimana siswa lebih banyak menghabiskan waktunya di luar dari pada di sekolah. Sedangkan jika dilihat dari guru yang mengajarkan matematika, ketidak sukaan siswa terhadap matematika bisa dikarenakan gaya guru mengajar yang kurang menarik, metode mengajar guru yang monoton hingga pada pribadi guru yang kurang menyentuh hati siswa.

Dari hasil survey peneliti (tanggal 25 Februari 2015) berupa pemberian tes diagnosis kepada siswa SMA Free Methodist 2 menunjukkan bahwa 83,33\% dari jumlah siswa kesulitan menggambarkan kurva dari sebuah integral, dan $10 \%$ dari jumlah siswa tidak paham sama sekali dengan permasalahan yang ada dalam soal. Kurangnya pemahaman konsep siswa tersebut dapat dilihat dari contoh soal dalam menentukan integral-integral tak tentu dan integral tentu, menghitung integral Riemann dan menggambarkan grafiknya, menentukan luas daerah di bawah sebuah kurva dengan batas a dan b, serta menentukan luas daerah di bawah beberapa kurva.

Atas alasan inilah penelitian ini sangat perlu dilakukan di sekolah tersebut, agar ada bahan masukan dan pertimbangan dalam menyikapi kejenuhan dan keterbatasan siswa saat belajar matematika integral, sehingga pola berpikirnya dapat dikembangkan. Penelitian ini juga akan dapat terlaksana dengan baik, karena didukung oleh laboratorium yang sangat memadai serta sarana belajar siswa yang sebagian besar sudah memiliki laptop sendiri.

Penerapan model pembelajaran Berbasis Masalah (PBL) merupakan salah satu dari solusi banyaknya permasalahan-permasalahan yang muncul di atas. Bantuan ICT seperti software Autograph dan Geogebra juga dapat menarik minat siswa terhadap pembelajaran matematika yang selama ini mereka anggap membosankan. Berdasarkan permasalahan di atas, serta beberapa solusi yang disebutkan sebelumnya peneliti 
mencoba untuk menggabungkan model pembelajaran berbasis masalah, dengan media teknologi komputer (Autograph dan Geogebra), untuk meningkatkan kemampuan pemahaman konsep dan kemampuan berpikir kritis siswa.

Istilah Pembelajaran Berbasis Masalah (PBM) di adopsi dari istilah Inggris Problem Based Instruction (PBI). Model pembelajaran berbasis masalah ini telah dikenal sejak zaman John Dewey (Trianto, 2011: 91). Model PBM atau Problem Based Instruction (PBI) juga dikenal dengan nama lain seperti Project Based Teaching (Pembelajaran Proyek), Experience Based Instruction (Pembelajaran Berdasarkan Pengalaman), Authentic Learning (Belajar Autentik), dan Anchored Instruction (pembelajaran bermakna atau berakar pada kehidupan).

Model PBL ini sangat baik apabila dipadukan dengan media teknologi terutama pada penggunaan Autograph dan Geogebra, karena hal ini dapat membantu mengembangkan daya kreativitas dan meningkatkan kemampuan berpikir siswa melalui investigasi yang mereka lakukan sehingga pemahaman konsep siswa terhadap pembelajaran matematika dapat meningkat.

Dari uraian di atas maka penulis tertarik untuk melakukan penelitian dengan judul "Peningkatan Kemampuan Pemahaman Konsep Matematis Melalui Model Pembelajaran Berbasis Masalah Berbantuan Autograph dan Geogebra di SMA Free Methodist Medan". Untuk mengetahui peningkatan kemampuan pemahaman konsep matematis siswa pada kelompok siswa yang memperoleh pembelajaran melalui penerapan model PBL dengan menggunakan software Autograph dan Geogebra, dan untuk mengetahui interaksi antara model pembelajaran dengan kemampuan awal matematika siswa terhadap peningkatan kemampuan pemahaman konsep matematis siswa.

Beberapa penelitian yang relevan dengan penelitian ini, yaitu penelitian Sri Lestari (2010) dalam penelitiannya menyimpulkan bahwa: (a) adanya peningkatan kemampuan pemahaman matematis siswa yang memperoleh pembelajaran melalui penerapan model CPS dengan Autograph; (b) adanya peningkatan kemampuan berpikir kritis siswa yang memperoleh pembelajaran melalui penerapan model CPS dengan menggunakan Autograph; (c) Sikap siswa terhadap pembelajaran melalui penerapan model CPS dengan menggunakan Autograph adalah positif.

Selanjutnya Vira Afriati (2011), melakukan penelitian terhadap Peningkatan Pemahaman Konsep dan Komunikasi Matematik dengan Pendekatan Penemuan Terbimbing Berbantuan Software Autograph, ditemukan bahwa: (a) adanya peningkatan pemahaman konsep matematik siswa yang memperoleh pendekatan penemuan terbimbing berbantuan software, (b) siswa yang mendapat penemuan terbimbing berbantuan software Autograph lebih menunjukkan kektifan belajar dari siswa yang mendapat pendekatan biasa.

\section{METODE}

Penelitian ini bertujuan untuk meningkatkan kemampuan pemahaman konsep matematis siswa sekaligus mengetahui apakah terdapat interaksi antara model pembelajaran berbasis masalah berbantuan autograph dan geogebra dengan kemampuan awal matematika siswa terhadap peningkatan kemampuan pemahaman konsep matematis siswa. Penelitian ini merupakan penelitian quasi eksperiment (eksprimen semu) yang dilaksanakan di SMA Free Methodist Medan. 
Arikunto (2006:130) menyatakan bahwa populasi adalah keseluruhan subjek penelitian. Populasi dalam penelitian ini adalah semua siswa kelas XII yang terdiri dari 4 kelas paralel dengan jumlah siswa keseluruhan 121 orang. Sugiyono (2009:118) menyatakan bahwa sampel adalah bagian dari jumlah dan karakteristik dari populasi. Sampel dalam penelitian ini adalah kelas XII IPA -2 dan XII IPA -3 yang kemudian ditetapkan sebagai kelas eksperimen I dan kelas eksperimen II. Dalam penelitian ini terpilih kelasXII IPA-2 sebagai kelas eksperimen I dengan jumlah siswa sebanyak 32 orang, dan XII IPA-3 sebagai kelas eksperimen II, dengan jumlah siswa sebanyak 30 orang. Instrumen yang digunakan untuk mengumpulkan data adalah tes kemampuan pemahaman konsep matematis. Soal tes dianalisis dengan perhitungan gain, uji normalitas, uji homogenitas, uji hipotesis dan uji interaksi.

\section{HASIL DAN PEMBAHASAN}

\section{Hasil}

Deskripsi Hasil $N$-gain Kemampuan Pemahaman konsep Matematika di Kelas Eksperimen I dan Kelas eksperiment II

Tabel 1.Hasil $N$-gain Kemampuan Pemahaman konsep Matematika Pada Kedua Kelas Sampel

\begin{tabular}{ccccc}
\hline Kelas & $\boldsymbol{X}_{\text {maks }}$ & $\boldsymbol{X}_{\min }$ & $\boldsymbol{X}_{\text {rata-rata }}$ & SD \\
\hline Eksperimen I & 1.00 & 0.44 & 0.79 & 0.14 \\
\hline Eksperimen II & 1.00 & 0.45 & 0.66 & 0.15 \\
\hline
\end{tabular}

Untuk lebih jelas perbedaannya maka digambarkan dalam diagram batang berikut ini.

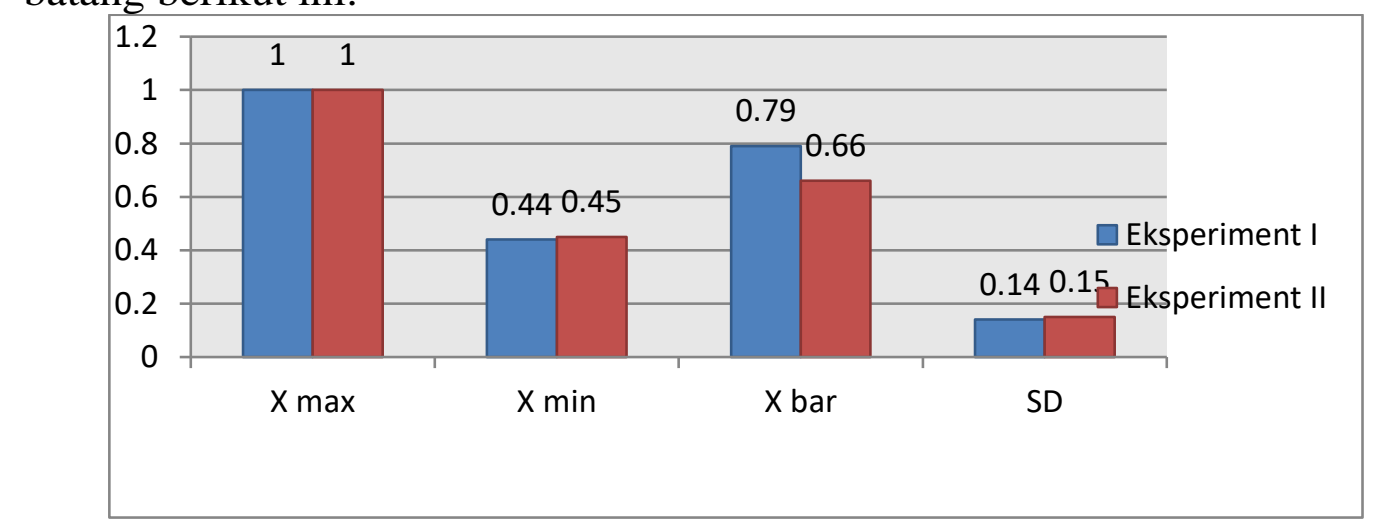

Gambar 1.Diagram Batang N-gain Kemampuan Pemahaman konsep Kelas Eksperimen I dan Eksperimen II

Pada Tabel 1 dan gambar 1 terlihat bahwa nilai tertinggi $N$-gain pada kedua kelas ekperimen sebesar 1 . Sedangkan untuk nilai rata-rata $N$-gain kelas eksperimen I sebesar 0,79 dan kelas eksperimen II sebesar 0,66. Jadi rata-rata $N$-gain kelas eksperimen I lebih tinggi sedikit dibandingkan rata-rata $\mathrm{N}$-gain dikelas eksperiment II. Dari perolehan ini maka selisih rata-rata $N$-gain antara kelas ekperimen I dan kelas eksperiment II sangat tipis yakni sebesar 0,13. Dari Tabel 4.10 juga terlihat nilai standar deviasi untuk kelas eksperiment I dan II sangat tipis sekali yakni 0, 14 untuk eksperimen I dan 0,15 untuk eksperimen II. 
Peningkatan Kemampuan Pemahaman Konsep Matematis Melalui Model......

\section{Uji Normalitas pada $N$-gain kemampuan pemahaman konsep matematika}

Hipotesis yang diuji untuk mengetahui normalitas kelompok data $\mathrm{N}$-gain kemampuan pemahaman konsep matematik adalah:

$\mathrm{H}_{0}: \mathrm{f}(\mathrm{x})=$ normal

$\mathrm{H}_{\mathrm{a}}: \mathrm{f}(\mathrm{x}) \neq$ normal

Tabel 2. Tests of Normality

\begin{tabular}{lccccccc} 
& \multicolumn{3}{c}{ Kolmogorov-Smirnov } & \multicolumn{3}{c}{ Shapiro-Wilk } \\
\cline { 2 - 8 } & Statistic & df & & Sig. & Statistic & Df & \multicolumn{1}{c}{ Sig. } \\
\hline EKS1 & .109 & 30 & $.200^{*}$ & .947 & 30 & .138 \\
EKS2 & .159 & 30 & .051 & .949 & 30 & .161 \\
\hline a. Lilliefors Significance Correction & & & & & \\
*. This is a lower bound of the true significance. & & & &
\end{tabular}

Dari hasil uji Kolmogorov-Smirnov test tersebut, diketahui bahwa nilai Signifikansi kelas eksperimen I sebesar 0.200 sedangkan kelas eksperimen II sebesar 0.051 . Karena nilai signifikansi kelas eksperimen I $(=0,200)$ maka sig eks I > $\alpha(0,2000>0,05)$ sehingga data $N$-gain kelas eksperimen I berdistribusi normal, dan untuk kelas eksperimen II nilai sig $>\alpha(0,051>0,05)$, artinya data $N$-gain kelas eksperimen II juga berdistribusi normal. Jadi data $N$-gain kelas eksperimen I dan kelas eksperimen II berasal dari data berdistribusi normal. Dengan demikian data $N$-gain kemampuan pemahaman konsep secara keseluruhan dapat disimpulkan berdistribusi Normal.

\section{Uji Homogenitas pada $N$-gain kemampuan pemahaman konsep matematika}

Setalah melalui tahap uji normalitas, data $N$-gain juga harus melalui tahap uji Homogenitas. Pada penelitian ini uji homogenitas menggunakan uji F. Hipotesis yang diuji untuk mengetahui homogenitas kelompok data $N$-gain kemampuan pemahaman konsep matematika adalah:

$\mathrm{H}_{0}: \sigma_{1}^{2}=\sigma_{2}^{2}$

$\mathrm{H}_{\mathrm{a}}: \sigma_{1}^{2} \neq \sigma_{2}^{2}$

Keterangan:

$\sigma_{1}^{2}$ adalah varians skor kelompok model pembelajaran berbasis masalah berbantuan autograph

$\sigma_{2}^{2}$ adalah varians skor kemlompok model pembelajaran berbasis masalah berbantuan geogebra.

Tabel 3. Test of Homogenity of Variance

\begin{tabular}{llll|} 
Pemahamankonsep & & & \\
\hline Levene Statistic & $\mathrm{df1}$ & $\mathrm{df} 2$ & Sig. \\
\hline .056 & 1 & 58 & .814 \\
\hline
\end{tabular}

Dari hasil levene menggunakan program SPSS 16 tersebut, diketahui bahwa untuk pengujian homogenitas dengan uji Levene nilai sig $>\alpha(0.814>0,05)$ dan $\mathrm{F}$ hitung sehingga hipotesis nol diterima yang berarti semua populasi mempunyai varians yang sama/homogen. Dengan demikian data $N$-gain kemampuan pemahaman 
konsep secara keseluruhan dapat disimpulkan memliki varians yang sama atau homogen. Berdasarkan pengujian Normalitas dan homogenitas di atas disimpulkan bahwa data $N$-gain kemampuan pemahaman konsep berdistribusi normal dan memiliki varians yang sama/homogeny.

\section{Uji Hipotesis}

Setelah pengujian prasyarat analisis data di dapat bahwa $\mathrm{N}$-gain pemahaman konsep matematik berdistribusi normal dan memiliki varians yang sama/homogen maka analisis yang digunakan adalah analisis parametrik. Untuk hipotesis pertama menggunakan uji t kemudian hipotesis kedua menggunakan uji anava 2 jalur.

\section{Uji Hipotesis Pertama}

Dari hasil uji prasyarat analisis yakni uji normalitas dan homogenitas menunjukkan bahwa data $N$-gain kemampuan pemahaman konsep siswa berdistribusi normal dan varians dari setiap kelompok data sama, maka untuk menganalisisnya menggunakan uji statistik parametrik yakni menggunakan uji $t$ dengan hipotesis statistik yang harus diuji untuk kemampuan pemahaman konsep dirumuskan sebagai berikut:

$\mathrm{H}_{0}: \mu_{x}=\mu_{y}$

$\mathrm{H}_{\mathrm{a}}: \mu_{x} \neq \mu_{y}$

Keterangan:

$\mu_{x}$ : Peningkatan kemampuan pemahaman konsep matematis siswa yang diajarkan dengan pembelajaran model PBM berbantuan autograph.

$\mu_{y}$ : Peningkatan kemampuan pemahaman konsep matematis yang diajarkan dengan pembelajaran model PBM berbantuan geogebra.

Berikut ini diperlihatkan hasil uji t $N$-gain kedua kelas sampel menggunakan SPSS 16:

Tabel 4. Hasil Uji t Kemampuan Pemahaman Konsep Matematis

\begin{tabular}{|c|c|c|c|c|c|c|c|c|c|c|}
\hline & & \multicolumn{9}{|c|}{ Levene's Test for Equality of Variances } \\
\hline & & \multirow[t]{2}{*}{$\mathrm{F}$} & \multirow[t]{2}{*}{ Sig. } & \multirow[t]{2}{*}{ T } & \multirow[t]{2}{*}{ df } & \multirow[t]{2}{*}{$\begin{array}{l}\text { Sig. } \\
\text { tailed) }\end{array}$} & \multirow[t]{2}{*}{$\begin{array}{l}\text { (2- Mean } \\
\text { Difference }\end{array}$} & \multirow[t]{2}{*}{$\begin{array}{l}\text { Std. Error } \\
\text { Difference }\end{array}$} & \multicolumn{2}{|c|}{$\begin{array}{l}\text { 95\% Confidence } \\
\text { Interval of the } \\
\text { Difference }\end{array}$} \\
\hline & & & & & & & & & Lower & Upper \\
\hline \multirow[t]{2}{*}{$\begin{array}{l}\text { Pemahaman } \\
\text { konsep }\end{array}$} & $\begin{array}{l}\text { Equal variances } \\
\text { assumed }\end{array}$ & .056 & .814 & 3.554 & 58 & .001 & .13100 & .03686 & .05721 & 20479 \\
\hline & $\begin{array}{l}\text { Equal variances not } \\
\text { assumed }\end{array}$ & & & 3.554 & 57.708 & .001 & .13100 & .03686 & .05720 & .20480 \\
\hline
\end{tabular}

Berdasarkan hasil perhitungan pada tabel 4 di atas dengan menggunakan uji t

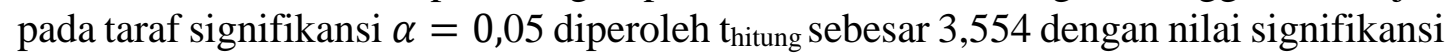
0,001 sedangkan $t_{\text {tabel }}$ sebesar 2,00 . Karena thitung $(=3,554)>t_{\text {tabel }}(=2,00)$ dan nilai signifikansi $(=0,001)<\alpha(=0,05)$, sehingga $\mathrm{H}_{0}$ ditolak. Maka dapat disimpulkan bahwa peningkatan Kemampuan Pemahaman Konsep matematik siswa yang dia jarkan melalui pembelajaran berbasis masalah berbantuan autograph lebih tinggi dari pada yang diajarkan melalui pembelajaran berbasis masalah berbantuan geogebra.

\section{Uji Hipotesis Kedua} berikut:

Hipotesis yang diajukan untuk di uji dengan uji ANAVA dirumuskan sebagai 
Peningkatan Kemampuan Pemahaman Konsep Matematis Melalui Model......

$\mathrm{H}_{0}: \alpha_{i} \beta_{j}=0$

$\mathrm{H}_{\mathrm{a}}$ : Minimal salah satu $\alpha_{i} \beta_{j} \neq 0$

Ket:

$\mathrm{i}=1,2$ dan $\mathrm{j}=1,2,3$

$\alpha$ : Pendekatan pembelajaran

$\beta$ : Kelompok KAM.

Kriteria pengujian, jika nilai significance (sig) lebih besar dari $\alpha=0,05$, maka $\mathrm{H}_{0}$ diterima, dalam hal lainnya di tolak.

Tabel 5. Hasil Uji Anava Berdasarkan Pembelajaran dan Kategori KAM Tests of Between-Subjects Effects

\begin{tabular}{llllll}
\multicolumn{2}{l}{ Dependent Variable:gain } & \multicolumn{5}{l}{ Type III Sum of } \\
Source & Squares & Df & Mean Square & F & Sig. \\
\hline Corrected Model & $.864^{\mathrm{a}}$ & 5 & .173 & 16.226 & .000 \\
Intercept & 28.006 & 1 & 28.006 & $2.629 \mathrm{E} 3$ & .000 \\
Pembelajaran & .291 & 1 & .291 & 27.315 & .000 \\
Kam & .539 & 2 & .269 & 25.288 & .000 \\
pembelajaran * kam & .058 & 2 & .029 & 2.737 & .074 \\
Error & .575 & 54 & .011 & & \\
Total & 33.224 & 60 & & & \\
Corrected Total & 1.440 & 59 & & & \\
\hline
\end{tabular}

a. R Squared $=, 600$ (Adjusted R Squared $=, 563$ )

Dari tabel 5. terlihat bahwa untuk faktor pembelajaran dan KAM, diperoleh nilai signifikansi sebesar 0,74. Karena nilai signifikansi lebih besar dari nilai taraf signikan 0,05, maka Ho diterima, yang berarti tidak terdapat interaksi antara pendekatan pembelajaran dengan kemampuan awal siswa terhadap peningkatan kemampuan pemahaman konsep matamatik siswa. Jadi, peningkatan kemampuan pemahaman konsep matematik siswa disebabkan oleh perbedaan pembelajaran yang digunakan bukan karena kemampuan awal matematika siswa. Dengan kata lain, tidak terdapat pengaruh secara bersama yang diberikan oleh pembelajaran dan KAM.

\section{KESIMPULAN DAN SARAN} berikut:

Berdasarkan hasil analsis data maka dapat ditarik kesimpulan sebagai

Peningkatan kemampuan pemahaman konsep matematik siswa yang diajarkan melalui pembelajaran berbasis masalah berbantuan autograph lebih tinggi dari pada yang diajarkan melalui pembelajaran berbasis masalah berbantuan geogebra. Tidak terdapat interaksi antara pendekatan pembelajaran dengan kemampuan awal siswa terhadap kemampuan pemahaman konsep matematik siswa. Berdasarkan hasil penelitian dengan menerapkan pembelajaran berbasis masalah berbantuan autograph dan geogebra, memberikan beberapa hal untuk perbaikan kedepannya. Untuk itu peneliti menyarankan kepada pihak-pihak tertentu yang berkepentingan dengan hasil penelitian ini, diantaranya:

Kepada Guru 
Untuk meningkatkan kemampuan pemahaman konsep siswa guru dapat menggunakan pembelajaran berbasis masalah berbantuan autograph dan geogebra terutama pada materi integral. Guru diharapkan perlu menambah wawasan tentang teori-teori pembelajaran yang lain (pembelajaran yang inovatif), dan dapat menerapkannya dalam pembelajaran. Guru diharapkan perlu menambah wawasan tentang indikator-indikator kemampuan pemahaman konsep khususnya pada indikator menggunakan, memanfaatkan dan memilih prosedur untuk menyelesaikan soal dengan tepat dari gambar yang diberikan.

Kepada Peneliti Lanjutan

Untuk peneliti selanjutnya, hendaknya melakukan penelitian tentang pembelajaran berbasis masalah berbantuan autograph atau Geogebra pada pokok bahasan yang berbeda. Untuk peneliti selanjutnya, hendaknya melakukan penelitian tentang pembelajaran berbasis masalah pada pokok bahasan yang sama (integral) dengan menggunakan software yang berbeda.

Untuk penelitian lebih lanjut hendaknya penelitian ini dapat dilengkapi dengan melakukan penelitian aspek-aspek kemampuan matematik yang lain yaitu kemampuan pemecahan masalah, koneksi, komunikasi dan representasi matematik secara lebih terperinci dan melakukan penelitian di tingkat sekolah yang belum terjangkau oleh peneliti saat ini.

\section{DAFTAR PUSTAKA}

Afriati, V. 2011. Peningkatan Pemahaman Konsep dan Komunikasi Matematika Siswa dengan Pendekatan Penemuan Terbimbing Berbantuan Software Autograph. Jurnal Paradikma, 5(1\&2).

Arikunto, S. 2006. Prosedur Penelitian Suatu Pendekatan Praktik. Edisi Revisi. Jakarta: Rineka Cipta.

Purwanto, N. 1995. Psikologi Pendidikan. Bandung: Remaja Rosdakarya.

Sanjaya, W. 2011. Strategi Pembelajaran Berorientasi Standar Proses Pendidikan. Jakarta: Kencana Prenada Media.

Sugiyono. 2009. Metode Penelitian Pendidikan Pendekatan kuantit atif, Kualitatif, Dan $R \& D$. Cetakan ke 7. Bandung: CV. Alfabeta.

Trianto. 2011. Mendesain Model-Model Pembelajaran Inovatif-Progresif, Konsep, Landasan, Dan Implementasinya Pada Kurikulum Tingkat Satuan Pendidikan (KTSP). Cetakan ke 4, Jakarta: Kencana. 